\title{
ON THE MECHANISM OF COMPLEMENT FIXATION.
}

\author{
By H. R. DEAN.
}

\section{(From the Bacteriological Laboratory of the Lister Institute.)}

ANY attempt to discuss the mechanism of the fixation of complement necessitates a brief reference to the well-known theories of Ehrlich and of Bordet.

The theory of Ehrlich assumes the existence of an amboceptor with two combining groups, one of which becomes attached to the antigen, while the other unites with the complement. The amboceptor is, in fact, supposed to form a link between the complement and the antigen. An haemolytic immune serum, for example, is supposed to contain an enormous number of amboceptors each of which possesses a cytophile group specific for the receptors of the red cell. After union has occurred between the receptors of the red cell and the cytophile group of the amboceptor, the other part of the amboceptor, the complementophile group is able to take up the complement. Bacteriolysis is thought to be brought about by the agency of a bacteriolytic amboceptor and the fixatiou of complement by a complement binding amboceptor. The amboceptor hypothesis has been supported by much indirect evidence but remains nevertheless a purely theoretical conception and does not in any case afford any real explanation of the experimental facts.

Bordet, on the other hand, considers that the complement is absorbed by the complex formed by the union of antigen and antibody. In 1901 Bordet and Gengou showed that complement is fixed by a mixture of an emulsion of B. typhosus with an antityphoid serum, and Gengou, in 1902, was able to fix complement in a mixture of a serum with its homologous antiserum. In a mixture of serum with its homologous antiserum, there occurs in the majority of cases a visible 
precipitate and the view was put forward that complement was taken up by the particles of the precipitate. This view was supported by Gay (1905), by Moreschi (1906) and by Moreschi and Pfeiffer (1906). It was, however, pointed out by Neisser and Sachs (1905), Muir and Martin (1906), Wassermann and Bruck (1905) and others that instances occurred when complement was fixed in mixtures in which no precipitate was visible and when no complement was bound in mixtures which produced a very considerable precipitate. The view was accordingly propounded that precipitation and complement fixation were separate and independent phenomena. The antibodies concerned in the formation of the precipitate were called precipitins and they were considered by many authors to be quite distinct from the antibodies which take part in complement fixation and which were held to be of the nature of amboceptors.

The literature dealing with the controversy is amply reviewed in an article by Sachs and Altmann (1909) and in an article by G. Meier (1909). For a brief consideration of the more important papers the reader may be referred to a paper in the Proceedings of the Royal Society of Medicine (Dean, 1911).

The chief evidence for the separate identity of the precipitins and the antibodies concerned in complement fixation rests on the numerous observations which show that complement is efficiently bound in a mixture of antigen and antibody in which no visible precipitation occurs. Such a mixture may be easily obtained by making a series of dilutions of antigen and adding to each tube a constant amount of antibody. In such a series of tubes complement fixation can as a rule be demonstrated for several tubes beyond the point where visible precipitation ceases. That is to say that for any quantity of antiserum a quantity of antigen may be found which when mixed with this quantity of antiserum produces no visible precipitate but which causes an efficient fixation of complement. Such an experiment is held to support the view that complement fixation and precipitation are separate and independent phenomena.

Our views as to how far the formation of a precipitate can be regarded as the essential cause of complement fixation must depend to a great extent on our knowledge of the formation and origin of the actual precipitate. The original theory assumes that the antibody which is called the precipitin, precipitates the antigen which is called the precipitinogen. The precipitin according to this view is an antibody which aggregates the particles of the antigen in the same fashion 
as an agglutinin is supposed to aggregate or agglutinate red cells or bacteria. Another view was expressed by Moreschi (1906) who stated that antigen and antibody united in various proportions to form a series of precipitates. Such precipitates would presumably contain variable proportions of the antigen and of the antibody according to the quantities of antigen and antibody present in the mixture. An entirely different explanation has been put forward by Welsh and Chapman (1906 to 1911) who have supported their conclusions by a series of exact quantitative experiments. These experiments show that in an ordinary precipitation experiment all or almost all of the precipitate is derived from the proteids of the antiserum. It is in fact the antigen (the so-called precipitinogen) which precipitates the proteids contained in the antiserum. Any quantity of an antiserum may be regarded as containing a definite content of precipitable material which can be precipitated by the addition of the homologous antigen, and the amount of precipitate which can be obtained from such a quantity of antiserum is a constant quantity which is independent within certain limits of the amount of antigen which is added.

If to a series of tubes containing a constant amount of antiserum there be added various amounts of antigen, several zones of precipitation may be arbitrarily differentiated. In the first place a great relative excess of antigen inhibits precipitation. In the next zone precipitation is very rapid. That is to say there is sufficient antigen present to quickly precipitate the precipitable material present in the antiserum. In these tubes large flocculi are rapidly formed and the process is soon complete. In the next zone, where a smaller amount of antigen is present, the process of precipitation is much slower. In these tubes there is sufficient antigen to precipitate all the precipitable substance of the antiserum provided that sufficient time is allowed. The entire process is slow and visible particles are only very slowly formed. In the last zone the tubes of which contain the smallest amounts of antigen, precipitation is very slow and incomplete. The quantity of antigen is insufficient to completely precipitate the precipitable content of the antiserum. These tubes show various grades of apparently homogeneous turbidity and opalescence and finally a point is reached where the amount of antigen present is insufficient to produce even a trace of opalescence.

If such an experiment be considered in the light of the theory of precipitation propounded by Welsh and Chapman many of the difficulties in connection with complement fixation disappear. 
In the first place it can be shown (Dean, 1911) that the best complement fixation takes place when antigen and antibody are mixed in such proportions that precipitation takes place slowly. If there is sufficient antigen present to produce the rapid formation of large flocculi, little or no complement is fixed. It is during the earliest stage in the aggregation of the molecules which are to form the precipitate, that complement is fixed.

It was also shown that to obtain the maximum complement fixation in a mixture of serum and antiserum it is necessary that the complement should be present from the beginning of the reaction. If antigen is mixed with antibody and an interval of half an hour allowed (at $37^{\circ} \mathrm{C}$.) before the complement is added, very much less fixation takes place. After a visible turbidity has made its appearance the capacity for fixing complement has to a large extent disappeared. In mixtures which contain very small amounts of antigen the process of precipitation is greatly prolonged. In such mixtures complement is efficiently fixed; for the early and incomplete stages of precipitation afford excellent conditions for the fixation of complement. In a mixture which contains so minute a quantity of antigen that no visible turbidity or opalescence appears it is probable that the earliest stages of the precipitation process do nevertheless take place and the formation of these minute invisible aggregations is the efficient cause of complement fixation. This appears to be the probable explanation of the fixation of complement in a mixture which contains too little antigen to produce a visible turbidity.

In carrying out a precipitation test it is possible to dilute the antigen to an enormous extent, frequently to 1 in 50,000 or 100,000 , in exceptional cases even to 1 in $1,000,000$. It is, however, customary to use a relatively large amount of the antiserum which is commonly employed in a dilution of 1 in 2 to 1 in 10 . If a smaller quantity of antiserum be chosen, for instance a 1 in 100 dilution, little or no precipitate will be produced. The reason for this is apparent from the experiments of Welsh and Chapman, for in such cases there is not sufficient antiserum present to produce an appreciable precipitate. In complement fixation experiments on the other hand relatively small quantities of the antiserum can be employed. A good antiserum can be always used in a dilution of 1 in 100, often in a dilution of 1 in 500 or 1 in 1000. If, however, a cubic centimetre of a 1 in 500 dilution of antiserum be mixed with an equal quantity of a suitable dilution of the homologous antigen, not even a trace of a precipitate can as a rule be 
detected. Such a mixture contains far too little of the precipitable substance of the antiserum for the formation of a visible precipitate. Nevertheless such a mixture may serve admirably for complement fixation. Such an experiment can easily be performed with any good antiserum and the result at first sight appears to afford evidence for the view that precipitation and complement fixation are separate and independent phenomena.

The experiments which are to be described are concerned with an attempt to explain the fixation of complement in mixtures which contain a quantity of antiserum insufficient to produce a visible precipitate. The fixation of complement in mixtures which contain a quantity of antigen insufficient to form a precipitate has already been considered in a paper published in the Proceedings of the Royal Society of Medicine, December 1911.

Before proceeding further, reference must be made to certain observations which have been made on the phenomenon of agglutination. Muir and Browning (1906) observed that if normal ox serum was added to a mixture of a suspension of ox corpuscles and the homologous antiserum (rabbit $v$. ox) a very intense agglutination of the corpuscles was produced. The fresh serum was found to greatly augment the agglutinative action of the antiserum on the corpuscles. They also stated that if the ox serum was heated for an hour at $55^{\circ} \mathrm{C}$. it lost the property of augmenting agglutination. In the same year Bordet and Gay (1906) published the results of very similar experiments. Bordet and Gay found that the property of increasing agglutination which was lost when ox serum was heated at $56^{\circ} \mathrm{C}$. could be restored by adding a little of the fresh serum of another animal. They concluded that there exists in ox serum a special substance which resists a temperature of $56^{\circ} \mathrm{C}$. and this substance they called "Colloide du bœuf." The substance was subsequently named conglutinin and the agglutination produced by the joint action of antiserum and ox serum has been called conglutination. Bordet and Streng (1909) subjected ox serum, after it had been heated to $56^{\circ} \mathrm{C}$, to dialysis. They found that the fraction which remained in solution favoured haemolysis, while the precipitate if re-dissolved in normal saline solution favoured agglutination. Streng (1909) in another communication adopted the conglutination method as a means of differentiating bacteria. By the addition of ox serum and complement he obtained marked agglutination of bacteria with a dilution of homologous antiserum, which by itself was too weak to produce any trace of 
agglutination. Streng stated that conglutinin could be separated from agglutinin by dialysis. The agglutinin, under these conditions, remained in solution, while the conglutinin was precipitated with the globulin fraction. Barikine (1910) effected a similar separation of agglutinin and conglutinin by saturating ox serum with carbon dioxide. As in the dialysis experiment, the conglutivin was precipitated with the euglobulin fraction, and the agglutinin remained in solution. Barikine also stated that the flocculi of a precipitate, formed in a mixture of antigen and antibody, could be conglutinated by the addition of fresh serum (complement) and heated ox serum (conglutinin). Dean (1911) precipitated the euglobulin from fresh guinea-pig serum, collected the precipitate and re-dissolved it in $0.85 \%$ sodium chloride solution. The solution of guinea-pig globulin was found to greatly increase the agglutination of sheep red cells by the homologous antiserum (rabbit $v$. sheep) and the agglutination of typhoid bacteria by antityphoid serum. If the antiserum was diluted to such an extent that it was no longer able to produce agglutination, marked clumping of the bacteria or cells could be produced by the addition of the guinea-pig globulin solution. It was, of course, shown by appropriate controls that the globulin acting by itself had no power to produce agglutination. If a mixture of sheep red cells, antiserum and guinea-pig globulin was incubated for an hour and then centrifugalised, it was found that the red cells had removed the agglutinating substance (? conglutinin) and the supernatant fluid had no power to produce agglutination if added to a second mixture of red cells and antiserum. The globulin was apparently adsorbed by the sensitised red cells. In a subsequent experiment red cells were lysed with distilled water and the solution was filtered to free it from stromata. In a mixture containing the soluble products of the red cells, antiserum and globulin solution, a fine flocculent precipitate formed. Control mixtures were also prepared: $(a)$ red cell solution with antiserum, $(b)$ red cell solution with globulin solution. In the control mixtures no precipitate formed. A similar phenomenon was observed when the guinea-pig globulin solution was added to a mixture of horse serum (antigen) with its homologous antiserum (rabbit $v$. horse), the antiserum being in this case used in a dilution of 1 in 100: this dilution was shown to be too weak to produce a precipitate when used in a simple mixture with the homologous antigen.

As a result of these experiments it was suggested that an essential part of the mechanism of agglutination was the precipitation of the globulin of the antiserum on the surface of the corpuscle or bacterium. 
When the antiserum was diluted to such an extent that there was not sufficient globulin present for agglutination, its action could be reinforced by the addition of the globulin obtained from normal serum.

The results, moreover, appeared to have a distinct bearing on the mechanism of complement fixation. It was determined to prepare mixtures of antigen with antiserum so diluted that little or no precipitate was formed and to add to such mixtures fresh guinea-pig serum. The results of these experiments are recorded in the following pages.

\section{Preparation of experimental material.}

The materials used as antigens were normal human serum, normal horse serum, and watery extracts of B. typhosus perpared by a method described in the Proceedings of the Royal Society of Medicine, 1911, Vol. IV, p. 251.

The antisera were prepared by the intravenous injection of rabbits. The antityphoid sera were prepared by the injection of emulsions of killed bacteria in normal saline.

The haemolytic system consisted of a 1 in 20 emulsion of washed sheep corpuscles in $0.85 \%$ sodium chloride solution. The haemolytic serum was prepared in the usual manner by the intravenous injection of rabbits with small quantities of washed corpuscles.

For the preparation of the mid-piece and end-piece fractions of the guinea-pig complement the carbon dioxide method of Liefmann (1909) was employed. The details of the method used may be found in a paper by Ledingham and Dean in the Journal of Hygiene, Vol. xII, No. 2, p. 154.

The results obtained by adding fresh guinea-pig serum (complement) to a mixture of antigen and antibody.

The materials used in this experiment were normal human serum and antihuman serum obtained by injecting a rabbit with human serum. Both sera were inactivated in the usual way by heating for half an hour at $56^{\circ} \mathrm{C}$.

The first part of the table illustrates the results of a precipitation experiment. Eleven dilutions of the antigen were prepared; the dilutions varied from 1 in 40 to 1 in 40,960. The bulk of the diluted antigen was in each case 1 c.c. Eight sets of antigen dilutions were prepared. To every tube of four of these sets was added 1 c.c. of a 
Scheme to illustrate the diagrams used in the Tables.

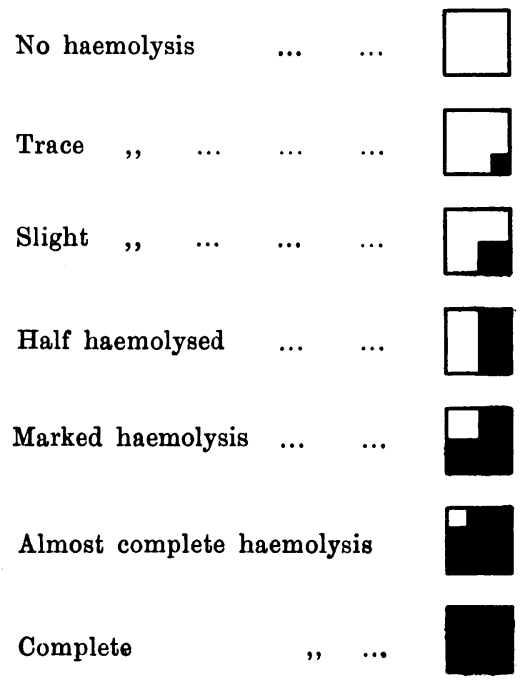

TABLE I. (Part I.) Precipitation Experiment.

\begin{tabular}{|c|c|c|c|c|c|c|c|c|}
\hline \multirow[b]{2}{*}{$\begin{array}{c}1 \text { c.c. } \\
\text { human serum } \\
\text { (antigen) } \\
\text { diluted }\end{array}$} & \multicolumn{2}{|c|}{$\begin{array}{l}+1 \text { c.c. antiserum } \\
\text { diluted } 1 \text { in } 40\end{array}$} & \multicolumn{2}{|c|}{$\begin{array}{l}+1 \text { c.c. antiserum } \\
\text { diluted } 1 \text { in } 80\end{array}$} & \multicolumn{2}{|c|}{$\begin{array}{l}+1 \text { c.c. antiserum } \\
\text { diluted } 1 \text { in } 160\end{array}$} & \multicolumn{2}{|c|}{$\begin{array}{c}+1 \text { c.c. saline } \\
\text { solution }\end{array}$} \\
\hline & $\begin{array}{c}+1 \text { c.c. } \\
\text { complement } \\
1 \text { in } 5\end{array}$ & $\begin{array}{l}\text { +1 c.c. } \\
\text { saline } \\
\text { solution }\end{array}$ & $\begin{array}{c}+1 \text { c.c. } \\
\text { complement } \\
1 \text { in } 5\end{array}$ & $\begin{array}{l}\text { +1 c.c. } \\
\text { saline } \\
\text { solution }\end{array}$ & $\begin{array}{c}+1 \text { c.c. } \\
\text { complement } \\
1 \text { in } 5\end{array}$ & 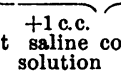 & $\begin{array}{l}+1 \text { c.c. } \\
\text { omplement } \\
1 \text { in } 5\end{array}$ & $\begin{array}{l}\text { +1c.c. } \\
\text { saline } \\
\text { soln. }\end{array}$ \\
\hline (1) 1 in 40 & +++ & +++ & $\stackrel{+}{\text { Cloudy }}$ & Cloudy & Clear & Clear & Clear & Clear \\
\hline (2) 1 in 80 & +++ & $++t$ & $\stackrel{+}{\text { Cloudy }}$ & $\stackrel{+}{\text { Cloudy }}$ & $\begin{array}{l}\text { Slightly } \\
\text { cloudy }\end{array}$ & ", & , & ", \\
\hline (3) 1 in 160 & +++ & +++ & +++ & ++ & $\stackrel{+}{\text { Cloudy }}$ & " & " & ", \\
\hline (4) 1 in 320 & $++t$ & +++ & +++ & ++ & + & , & , & ", \\
\hline (5) 1 in 640 & $+++t$ & +++ & +++ & ++ & + op & $\begin{array}{c}\text { Trace } \\
\text { palescence }\end{array}$ & ", & " \\
\hline (6) 1 in 1280 & $++t$ & +++ & +++ & + & + & Clear & , & ", \\
\hline (7) 1 in 2560 & $++t$ & $\underset{\text { Cloudy }}{+}$ & ++ & Cloudy & + & ," & " & ", \\
\hline (8) 1 in 5120 & ++ & Cloudy & $\stackrel{+}{\text { Cloudy }}$ & $\begin{array}{l}\text { Opal- } \\
\text { escent }\end{array}$ & + & , & , & ", \\
\hline (9) 1 in 10240 & ++ & $\begin{array}{c}\text { Trace } \\
\text { opalescence }\end{array}$ & Cloudy & Clear & + & " & , & ", \\
\hline (10) 1 in 20480 & + & Clear & Cloudy & ", & Cloudy & $"$ & ", & $"$ \\
\hline (11) 1 in 40960 & $\begin{array}{l}\text { Opal- } \\
\text { escent }\end{array}$ & $"$ & $\begin{array}{l}\text { Opal- } \\
\text { escent }\end{array}$ & ", & Clear & ", & ", & " \\
\hline $\begin{array}{l}\text { (12) } 1 \text { c.c. } \\
\text { saline soln. }\end{array}$ & Clear & Clear & Clear & Clear & Clear & Clear & Clear & Clear \\
\hline
\end{tabular}


TABLE I. (Part II.) Complement Fixation Experiment.

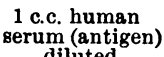

(1) 1 in 40

(2) 1 in 80

(3) 1 in 160

(4) 1 in 320

(5) 1 in 640

(6) 1 in 1280

(7) 1 in 2560

(8) 1 in 5120

(9) 1 in 10240

(10) 1 in 20480

(11) 1 in 40960

(12) 1 c.c. saline solution

$\overbrace{\substack{\text { Diluted } \\ 1 \text { in } 40}}^{+1 \text { c.c. antiserum }} \overbrace{\substack{\text { Diluted } \\ 1 \text { in } 80}}^{\substack{\text { Diluted } \\ 1 \text { in } 160}}$

+1 c.c. saline

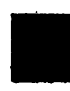

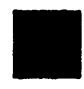

solution
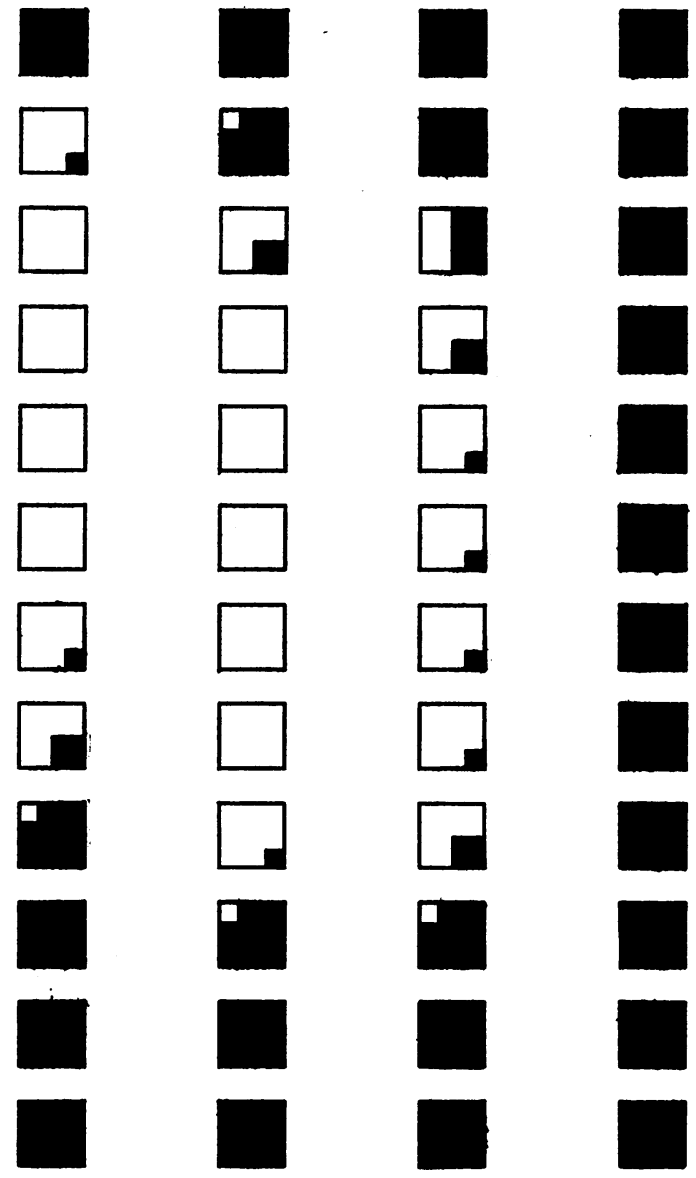

1 in 5 dilution of fresh guinea-pig serum. To each tube of the other four sets was added 1 c.c. of saline solution. Three dilutions of antiserum were prepared, namely 1 in 40,1 in 80 and 1 in 160 . One c.c. of each dilution of the antigen was then added to every tube of two sets, the one set containing complement in each case and the other set containing only antigen and saline. To the last two sets no antiserum was added, but each tube received 1 c.c. of normal saline. The tubes 
were incubated for five hours at a temperature of $37^{\circ} \mathrm{C}$. and were then placed overnight in a room at a temperature of $8^{\circ} \mathrm{C}$. The results were then read and recorded.

The crosses in the table indicate a deposit of precipitate and a clear supernatant fluid. The number of crosses represent very roughly the relative amount of precipitate in each tube. In some tubes precipitation was evidenced by a uniform turbidity which had not settled to form a deposit. In some cases some of the precipitate had deposited while the rest remained in suspension.

The experiment shows the amount of precipitate formed by various mixtures of antigen and antibody. These are represented in the righthand columns of each of the larger divisions. The left-hand columns show the influence of the addition of the fresh serum of the guinea-pig to these mixtures.

It will be seen that precipitation was much more evident in the sets to which guinea-pig serum was added. The tubes represented by the first two columns of the table contained 1 c.c. of a 1 in 40 dilution, that is to say 0.025 of the antiserum.

In the tubes which contained the larger quantities of antigen ( 1 in 40 to 1 in 1280) there was no appreciable difference in the precipitation between the two sets: in both cases a flocculent precipitate had completely separated from a clear supernatant fluid.

In the tubes which contained the smaller amounts of antigen there was a distinct difference between the two sets.

The tubes containing the complement (except Tube 11) showed definite deposits and a clear supernatant fluid while the corresponding tubes which had received no complement showed various stages of uniform turbidity or opalescence. In the tubes which contained complement the precipitation process had proceeded to the stage of formation of visible flocculi which had fallen to the bottom of the tube. In the tubes containing no complement the particles were too small to be individually visible and remained suspended in the fluid in the form of an apparently homogeneous turbidity.

In the tubes which contained half the amount of antiserum, namely, 1 c.c. of a 1 in 80 dilution the difference between the tubes which did contain complement and those which did not, was much more marked. In the case of the mixtures which contained the smaller quantities of antigen the tubes containing complement showed a deposit while those which contained no complement showed a uniform turbidity. In the case of the tubes which contained the larger quantities of antigen 
both sets showed deposits but the deposits in the tubes containing complement were definitely larger than the deposits in the control tubes without complement. When the amount of antiserum was reduced still further to 1 c.c. of a 1 in 160 dilution $(=0.00625$ c.c. of antiserum) a still greater difference was apparent. In the control set to which no complement was added there was no trace of precipitation except in Tube 5 in which a rather doubtful trace of opalescence was recorded. In the majority of the tubes to which complement had been added a small but perfectly definite precipitate was present. In the last two columns and in the bottom line (No. 12) the necessary control tubes are represented. The controls containing the human serum (antigen) and the antiserum in all the dilutions employed remained perfectly clear during the period of the experiment ( 20 hours). No turbidity or precipitate was produced by any of the mixtures of antiserum and complement or by any of the mixtures of antigen and complement.

The second part of the table represents the result of a complement fixation experiment in which the same dilutions of antigen and antiserum were employed as in the precipitation experiment.

Four sets of antigen dilutions were prepared and the bulk of the antigen dilution in each tube was 0.5 c.c. To each tube was then added $0 \div 5$ c.c. of a 1 in 10 dilution of fresh guinea-pig serum. To each of the tubes of the first column was then added 0.5 c.c. of a 1 in 40 dilution of the antiserum, to each of the tubes of the second column 0.5 c.c. of a 1 in 80 dilution of the antiserum, to each of the tubes of the third column 0.5 c.c. of a 1 in 160 dilution of the antiserum. The tubes of the fourth column constituted the antigen controls and received 0.5 c.c. of saline solution. The tubes numbered 12 in each column contained the same dilution of antiserum as the other tubes of the column but no antigen. All the tubes were then incubated at a temperature of $37^{\circ} \mathrm{C}$. for one hour. At the end of the hour all the tubes received 0.5 c.c. of a 1 in 400 dilution of haemolytic serum (rabbit $v$. sheep) and 0.5 c.c. of a 1 in 20 suspension of washed sheep corpuscles. All the tubes were then incubated for a further period of two hours.

On looking at Table I it will be seen that the increase in precipitation in the sets containing guinea-pig serum occurred in those tubes which contained the relative proportions of antigen and antiserum which were shown in the second part of the table to be suitable for the fixation of complement. That is to say, the zones of extra-precipitation corresponded fairly closely with the zones of complement fixation. In the case of the tubes which contained an antiserum dilution of 1 in 160 
practically no precipitation occurred in the tubes containing the mixture of antigen and antiserum while excellent complement fixation was obtained. A result such as this is frequently used as an argument in favour of the view that precipitation is separate and distinct from complement fixation. The table, however, shows that if fresh guinea-pig serum (complement) is added to such mixtures of antigen and antiserum a precipitate does actually form. If guinea-pig serum is added to a mixture of antigen and antiserum which will bind complement, a precipitate is formed even if no precipitate is visible in a simple mixture of the antigen and antibody. The fact that no precipitate is visible in the simple mixture of antigen and antibody is no evidence that complement fixation is independent of the formation of a precipitate.

It is necessary to state that the smaller precipitates shown in the table did not become visible during the first few hours after the commencement of the experiment. The precipitates recorded in the table were observed and recorded 20 hours after the antigen, antiserum and guinea-pig serum had been mixed. This observation is consistent with results previously published (Dean, 1911) which showed that mixtures of antigen and antibody in which the formation of a precipitate was slow were favourable to the fixation of complement.

The explanation of the extra precipitate caused by the presence of complement in a mixture of antigen and antibody is a matter of some difficulty. In mixtures which contain a large amount of antiserum and in which a bulky precipitate is formed, the addition of guinea-pig serum makes no appreciable difference to the amount of the precipitate. When, however, the amount of the antiserum in the mixture is very small the quantity of precipitable proteid (antiserum) is so small that the resulting precipitate is not visible. If to such a mixture there be added normal guinea-pig serum it is quite possible that the proteids of the guinea-pig serum are adsorbed by the minute particles of the specific precipitate. The particles of the precipitate are thus increased in size and become visible as a definite turbidity or precipitate. It is suggested that this adsorption of the proteids of the guinea-pig serum by the minute particles of a precipitate is the essential cause of the fixation of complement.

Another explanation might be afforded by supposing that the addition of complement did not cause any increase in the bulk of the precipitate, but merely acted by agglutinating or conglutinating the particles of the precipitate and in this fashion making the precipitate 
more easily visible. Barikine (1910) in fact explained his experiments in this way. After a consideration, however, of the experiment recorded in Table I and of numerous other similar experiments the conglutination explanation did not appear to account for the facts. It seemed for instance very doubtful if the quite definite precipitates obtained by adding guinea-pig serum to a 1 in 160 dilution of the antiserum (Table I) could be explained by a mere agglutination of an already formed precipitate. Further evidence on this point is afforded by the experiment recorded in Table III.

The effect of adding fresh guinea-pig serum to mixtures of an extract of B. typhosus with antityphoid serum.

Many experiments of the type of that recorded in Table I were performed and a similar result was in all cases obtained. In the experiment recorded in Table II the antigen was a distilled water extract of B. typhosus. The antiserum had been obtained by the intravenous injection of a rabbit with emulsions of killed typhoid bacteria. The experiment was carried out in essentially the same manner as that recorded in Table I. In the complement fixation experiment, three different quantities of complement were used in order to provide a roughly quantitative measure of the complement-binding power of the various mixtures employed. It will be seen that precipitation was far more marked in the set of tubes to which the guinea-pig serum was added. Similar results were obtained with other antigen-antibody systems.

The effect of adding various quantities of guinea-pig serum to a mixture of antigen and antibody.

In this experiment tubes were used the lower portions of which were narrow and calibrated in order that the amount of precipitate formed could be measured. Only one quantity of antigen was employed (3 c.c. of a 1 in 20 dilution of typhoid extract) and one quantity of the antiserum ( 3 c.c. of a 1 in 20 dilution of antityphoid-serum). The amount of precipitate formed by the simple mixture of the antigen and antibody is shown in the second column, Tube 8 . The actual bulk of the precipitate was 0.01 c.c.

The table shows that the addition of guinea-pig serum to this mixture caused a very marked increase in the bulk of the precipitate. 
TABLE II.

Precipitation Experiment.
(2) 1 in 20 Large flocculent
precipitate-
clear fluid
(rabbit) diluted 1 in 20

Precipitation. Result after 24 hours.

The middle column shows the precipitation produced by mixing various quantities of typhoid extract with a constant quantity of antityphoid serum. The left-hand column shows the result obtained when fresh guinea-pig serum is added to these various mixtures of extract and serum. The third column shows that no precipitate is produced when normal guinea-pig serum is mixed with typhoid extract. Tube 8 in the left-hand column shows that no precipitate is produced by the mixture of the antityphoid serum with normal guinea-pig serum.
Complement Fixation Experiment.

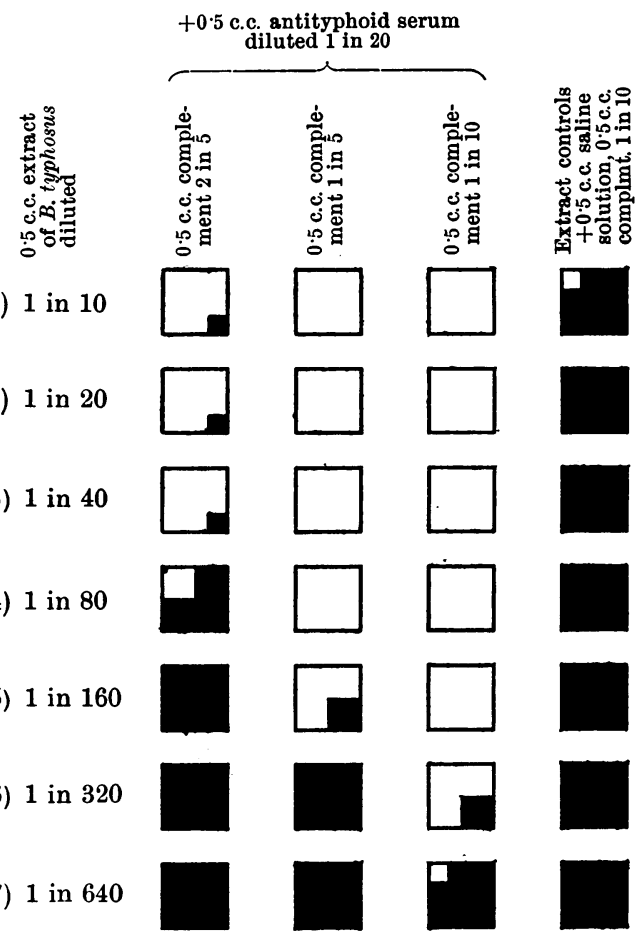

(8) 0.5 c.c. saline soln. (serum control)
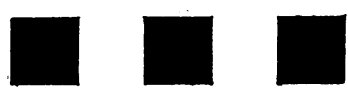

Complement Fixation.

This experiment shows the amount of complement fixed by mixtures of typhoid extract and antiserum identical with those used in the precipitation experiments. The dilutions of extract, antiserum and fresh guinea-pig serum (complement) were all used in a bulk of 0.5 c.c. After one hour's incubation each tube received 0.5 c.c. of a 1 in 20 suspension of sheep corpuscles and 0.5 c.c. of a 1 in 300 dilution of haemolytic serum (rabbit $v$. sheep). The results were read after a second period of incubation lasting two hours. 
In the tubes containing the large quantities of guinea-pig serum the bulk of the precipitate was twice and three times as great as the precipitate produced in the simple mixture of antigen and antibody. It is difficult to escape the conclusion that the larger precipitates were partly derived from the proteids of the guinea-pig serum.

\section{TABLE III.}

To illustrate result obtained by adding various amounts of fresh guinea-pig serum (complement) to a mixture of typhoid extract and antityphoid serum.

\begin{tabular}{|c|c|c|c|c|c|c|}
\hline & \multirow[b]{2}{*}{$\begin{array}{l}3 \text { c.c. of guinea- } \\
\text { pig serum }\end{array}$} & \multicolumn{2}{|c|}{$\begin{array}{l}+3 \text { c.c. antityphoid serum } 1 \text { in } 20 \\
+3 \text { c.c. typhoid extract } 1 \text { in } 20\end{array}$} & \multirow{2}{*}{$\begin{array}{c}+3 \text { c.c. saline } \\
\text { golution }+3 \text { c.c. } \\
\text { typhoid extract } \\
1 \text { in } 20 \\
\text { i- } \\
\text { After } 24 \\
\text { hours }\end{array}$} & \multirow{2}{*}{$\begin{array}{c}\text { +3 c.c. anti- } \\
\text { typhoid serum } \\
+3 \text { c.c. } \\
\text { saline solution } \\
\text { After } 24 \\
\text { hours }\end{array}$} & \multirow{2}{*}{$\begin{array}{c}\text { +6 c.c. } \\
\text { saline } \\
\text { solution } \\
\text { After } 24 \\
\text { hours }\end{array}$} \\
\hline & & After 6 hours & $\begin{array}{l}\text { After } 24 \mathrm{hrs} \text {. centri- } \\
\text { fugalised deposit }\end{array}$ & & & \\
\hline 1 & $\begin{array}{l}\text { Undiluted } \\
\text { Diluted }\end{array}$ & Large flocculi & 3 & Clear & Clear & Clear \\
\hline 2 & 1 in $2 \frac{1}{2}$ & ", & 3 & , & ," & ", \\
\hline 3 & 1 in 5 & ", & 2 & ", & , & $"$ \\
\hline 4 & 1 in 10 & Small particles & 1 & ", & , & , \\
\hline 5 & 1 in 20 & Turbid & 1 & ," & ", & , \\
\hline 6 & 1 in 40 &, & 1 & , & , & , \\
\hline 7 & 1 in 80 & , & 1 & , & , & $"$ \\
\hline 8 & $\begin{array}{l}\text { Control } 3 \text { c.c. } \\
\text { saline solutior }\end{array}$ & n & 1 & , & $"$ & ", \\
\hline
\end{tabular}

All the tubes were incubated for 6 hours at $37^{\circ} \mathrm{C}$. The tubes were then placed in a cool room at $8^{\circ} \mathrm{C}$. After 24 hours the tubes in the first column were centrifugalised and the deposits observed. All the control tubes remained absolutely clear.

The effect of adding normal rabbit serum, normal ox serum and heated guinea-pig serum to mixtures of antigen and antibody.

The controls employed in all these experiments gave perfectly satisfactory results. In no case did either antigen or antibody in the dilution employed cause any precipitation when mixed with guinea-pig serum. Many of the experiments were, however, repeated, and fresh normal rabbit serum was substituted for the normal guinea-pig serum. In these experiments the possibility that the results obtained were due to the action of normal precipitins in the rabbit or guinea-pig serum could be definitely excluded. The results of the experiments were similar to those obtained by the use of normal guinea-pig serum.

In view of the remarkable "conglutinative" property which ox serum has been shown to possess it was decided to try normal ox serum in place of normal guinea-pig serum. The addition of normal ox serum 
to a mixture of typhoid extract and antityphoid serum produced an increase in the precipitation. This increase was about the same as that produced by the addition of an equal quantity of normal guinea-pig serum.

In another experiment some normal guinea-pig serum was heated for half an hour at $56^{\circ} \mathrm{C}$. A series of dilutions of the heated and of the unheated guinea-pig serum were then added to a mixture of typhoid extract and antityphoid serum. This experiment was carried out in the same fashion as the experiment recorded in Table III. There was very little difference between the results obtained with the fresh guinea-pig serum and those obtained with the heated guinea-pig serum. The increased precipitation was a trifle more marked in the tubes which contained the fresh serum. This shows that the action of the normal serum in these experiments does not depend on the presence of complement.

\section{The part played by the two fractions of the complement in fixation experiments.}

Before proceeding further it is necessary to refer to the experiments of Ferrata and others who have shown that complement must be no longer regarded as a single substance.

Ferrata (1907) dialysed fresh guinea-pig serum against distilled water. He then separated the precipitated euglobulin and re-dissolved it in saline solution. To the residue which remained in solution he added sufficient sodium chloride to make the solution isotonic with blood serum. He thus obtained two fractions, (1) a globulin fraction, and (2) a so-called albumen fraction. He found that neither fraction could act as complement but that excellent complementing could be obtained by adding a mixture of the two fractions to corpuscles and haemolytic serum. Brand (1907) repeated these experiments and called the fraction which was precipitated with the euglobulin the midpiece (Mittelstuick) and the fraction which remained in solution the end-piece (Endstuick). These names are convenient and are now in general use. Ferrata's method for separating the fractions was, however, found to be difficult and somewhat unreliable and two other methods have been devised. Liefmann (1909) diluted one part of fresh guineapig serum with nine parts of distilled water and saturated the mixture with carbon dioxide gas. The precipitated euglobulin is separated in a centrifuge, washed with distilled water and re-dissolved in salt solution 
This constitutes the mid-piece solution. To the supernatant fluid is added enough sodium chloride to make the solution isotonic with blood serum. This constitutes the end-piece solution. Sachs and Altmann (1909) effected a separation of the two fractions by using very dilute hydrochloric acid.

It should be noticed that all these methods consist in producing a precipitate of the euglobulin of the solution. The mid-piece of the complement is found to be precipitated with the euglobulin fraction of the serum.

The behaviour of the two fractions of the complement when fresh guinea-pig serum (the whole complement) is added to a mixture of antigen and antibody has been investigated by several authors.

Skwirsky (1910) stated that in the Wassermann reaction the midpiece fraction was bound while the end-piece remained absolutely unbound. The same result was obtained when complement was added to a mixture of tuberculin and antituberculin or to a mixture of horse serum and antihorse serum (rabbit $v$. horse). It was also shown in the case of certain sera, which bad the property of spontaneously binding complement, that only the mid-piece fraction was taken up. In haemolysis experiments on the other hand both fractions of the complement disappeared. Skwirsky also experimented with suspensions of kaolin which he found to take up both fractions of the complement.

Henderson Smith (1910) found that in precipitin reactions and in Wassermann reactions the mid-piece only was fixed. Spontaneously binding serums and bacterial extracts were also found to bind mid-piece only. Sachs and Bolkowska (1910) mixed red corpuscles, haemolytic serum and complement, and allowed the mixture to stand at $0^{\circ} \mathrm{C}$. When a small quantity of the antiserum was used no complement was bound, when the amount of antiserum in the mixture was increased the midpiece alone was taken up. When very large quantities of antiserum were employed both fractions of the complement were fixed and haemolysis followed. Amako (1910) found that in specific reactions between antigen and antibody the mid-piece was chiefly fixed while the end-piece remained free in solution. Occasionally partial binding of the end-piece occurred. Suspensions of kaolin, yeast cells and oxide of iron were found to bind both fractions of the complement. In the Wassermann reaction the mid-piece only was fixed. Amako concluded that the Wassermann reaction must for this reason be regarded as a specific reaction between an antigen and an antibody. Gengou (1911) found that in a suitably arranged experiment sensitised red corpuscles, 
sensitised cholera vibrios and specific precipitates fixed the whole of the mid-piece, while part at least of the end-piece remained free. A precisely similar result was obtained with an emulsion of barium sulphate. Gengou concludes that no distinction need be drawn between the absorption of complement by a barium sulphate precipitate and the absorption of complement which occurs in a complement fixation or in a haemolytic experiment.

From these experiments of Gengou it appears that there is no essential difference between specific and non-specific complement fixation. If complement is added to any complement binding substance or mixture of substances it is found that the mid-piece is more easily bound than the end-piece. If the mixture has only slight complement binding properties some or all of the rnid-piece is fixed while the endpiece remains free. If the mixture has stronger complement binding properties all the mid-piece is bound and some of the end-piece. Very strong mixtures may bind the whole of both fractions.

We are now in a position to consider the various conditions under which complement is fixed. When fresh guinea-pig serum is dialysed against distilled water, when it is diluted with distilled water and saturated with carbon dioxide, when it is acidified with weak hydrochloric acid, the particles of euglobulin of the serum are aggregated and precipitated and when this occurs the mid-piece of the complement is fixed. The mid-piece of the complement is, in fact, taken up by the precipitate of euglobulin and if the precipitate is re-dissolved or re-suspended in saline the presence of the mid-piece can be demonstrated $^{1}$. Now it has been shown in the experiments already described (Tables I, II and III) that when fresh guinea-pig serum is added to

1 These methods for separating the two fractions of the complement are successful because the mid-piece is much more readily taken up by the precipitate than the end-piece. In carrying out such a separation of the two fractions the experimental conditions are arranged to ensure that the mid-piece is fixed while the end-piece remains as far as possible in solution. The difference is, however, in this case also a quantitative one, for under suitable conditions it can be shown that the end-piece is also, though far less readily, fixed by a suspension of euglobulin.

A series of dilutions of a suspension of euglobulin are added to a constant quantity of end-piece. The various tubes are then incubated at $37^{\circ} \mathrm{C}$. for one hour at the end of which time a mixture of red corpuscles, haemolytic serum and mid-piece (persensitised corpuscles) are added to each tube. The tubes are then again incubated and the amount of lysis in each tube is recorded. Such an experiment shows that euglobulin suspended in salt solution has distinct power of taking up end-piece. The fact that the end-piece fraction is taken up by a suspension of euglobulin in salt solution is the probable explanation of the so-called Brand phenomenon. Further experiments on this point may be found in the Journal of Hygiene, Vol. xII, No. 2, p. 183 (Ledingham and Dean). 
a suitable mixture of antigen and antibody an increase of precipitation occurs. The results of these experiments make it appear probable that under these conditions a part of the precipitate is actually derived from the proteids of the guinea-pig serum. That is to say, the reaction between antigen and antibody results in a partial precipitation of the proteids of the guinea-pig serum and the mid-piece of the complement is taken up by this precipitate in the same fashion as it is taken up by the precipitate of euglobulin produced by the action of carbon dioxide or weak hydrochloric acid.

The next step was to show that it is the euglobulin fraction of guinea-pig serum which is precipitated by the mixture of antigen and antiserum. That this is the case will be seen from the results recorded in Table IV.

\section{The effect obtained by adding a solution of euglobulin to a mixture of typhoid extract and antityphoid serum.}

The euglobulin preparations used in this experiment were prepared by Liefmann's method. The greatest care was taken to obtain a perfectly clear solution of euglobulin. This euglobulin solution contained the mid-piece of the complement. It is described in the table as 1 in 10 mid-piece. This means that the euglobulin precipitate obtained from 1 c.c. of guinea-pig serum was re-dissolved in 10 c.c. of saline solution.

This experiment was performed in precisely the same manner as that recorded in Table $I$.

The first part of the table shows the result of adding the euglobulin solution to various mixtures of typhoid extract (antigen) and antityphoid serum (antibody). All these tubes were incubated for four hours at $37^{\circ} \mathrm{C}$. and then allowed to stand overnight in a cool room at a temperature of $8^{\circ} \mathrm{C}$. The results were then read and recorded. The relative amounts of the deposit are indicated by the number of crosses in the table. In the mixtures which contained the largest quantity of antiserum, 1 c.c. of a 1 in 10 dilution, the addition of the euglobulin solution produced no visible increase in the amount of the precipitate. In the mixtures which contained the smaller quantities of antiserum there was a very evident difference between the tubes which contained the euglobulin and the control tubes which did not. The zones of the precipitation corresponded fairly well with the zones of complement fixation shown in the second part of the table. In the 
TABLE IV.

Precipitation Experiment.

\begin{tabular}{|c|c|c|c|c|c|c|c|c|}
\hline \multirow[b]{2}{*}{$\begin{array}{l}\text { 1 c.c. of } \\
\text { extract of } \\
\text { B. typhosus } \\
\text { diluted }\end{array}$} & \multicolumn{2}{|c|}{$\begin{array}{l}\text { +1 c.c. antityphoid } \\
\text { serum diluted } 1 \text { in } 10\end{array}$} & \multicolumn{2}{|c|}{$\begin{array}{l}+1 \text { c.c. antityphoid } \\
\text { serum diluted } 1 \text { in } 40\end{array}$} & \multicolumn{2}{|c|}{$\begin{array}{l}\text { +1 c.c. antityphoid } \\
\text { serum diluted } 1 \text { in } 160\end{array}$} & \multicolumn{2}{|c|}{$\begin{array}{c}\text { +1 c.c. } \\
\text { saline solution }\end{array}$} \\
\hline & $\overbrace{\substack{+1 \text { c.c. } \\
\text { mid-piece }}}$ & $\begin{array}{l}+1 \text { c.c. } \\
\text { saline } \\
\text { solution }\end{array}$ & $\begin{array}{c}+1 \text { c.c. } \\
\text { mid-piece } \\
1 \text { in } 10\end{array}$ & $\begin{array}{c}+1 \text { c.c. } \\
\text { saline } \\
\text { solution }\end{array}$ & $\begin{array}{l}+1 \text { c.c. } \\
\text { mid-piece } \\
1 \text { in } 10\end{array}$ & $\begin{array}{l}+1 \text { c.c. } \\
\text { saline } \\
\text { solution }\end{array}$ & $\begin{array}{c}+1 \text { c.c. } \\
\text { mid-piece } \\
1 \text { in } 10\end{array}$ & $\begin{array}{l}+1 \text { c.c. } \\
\text { saline } \\
\text { solution }\end{array}$ \\
\hline 1 in $2 \frac{1}{2}$ & ++ & ++ & Clear & Clear & Clear & Clear & Clear & Clear \\
\hline 1 in 10 & $++t+$ & $++t+$ & + & , & , , & , & ", & , \\
\hline 1 in 40 & ++++ & $++t+$ & + & $\begin{array}{c}\text { Trace } \\
\text { opalescence }\end{array}$ & $\begin{array}{l}\text { Opales- } \\
\text { cence }\end{array}$ & ", & ", & ", \\
\hline 1. in 160 & ++ & ++ & + & ", & $\begin{array}{l}\text { Slight } \\
\text { turbidity }\end{array}$ & , & , & ", \\
\hline 1 in 640 & + & Clear & $\begin{array}{l}\text { Opales- } \\
\text { cence }\end{array}$ & Clear & $\begin{array}{c}\text { Trace } \\
\text { opalescence }\end{array}$ & e & " & ", \\
\hline $\begin{array}{l}1 \text { c.c. } \\
\text { saline } \mathrm{s}\end{array}$ & Clear & ", & Clear & " & Clear & , & ", & ", \\
\hline
\end{tabular}

Complement Fixation Experiment.

$\begin{array}{ll}0.5 \text { c.c. } & +0.5 \text { c.c. anti- } \\ \text { extract of } \\ \begin{array}{l}\text { B. typhosus } \\ \text { diluted }\end{array} & \text { typhoid serum } \\ \text { diluted } 1 \text { in } 10\end{array}$

(1) 1 in $2 \frac{1}{2}$

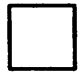

(2) 1 in 10

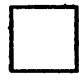

(3) 1 in 40

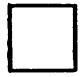

(4) 1 in 160

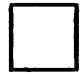

(5) 1 in 640

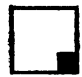

(6) 0.5 c.c. saline soln.

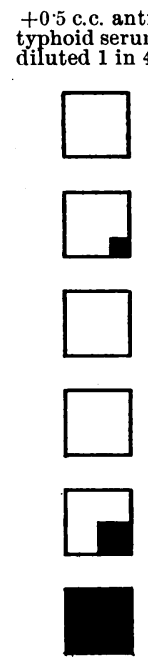

+0.5 c.c. anti-
typhoid serum typhoid serum
diluted 1 in 160
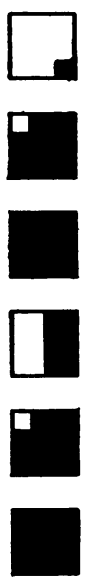

+0.5 c.c. saline solution
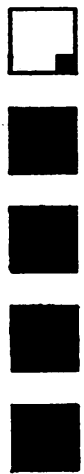

complement fixation experiment, the same dilutions of antigen and antibody were used as in the precipitation experiment. To every tube was added 0.5 c.c. of fresh guinea-pig serum diluted 1 in 10. After incubation for one hour at $37^{\circ} \mathrm{C}$. each tube received 0.5 c.c. of a 1 in 20 suspension of sheep corpuscles and 0.5 c.c. of a 1 in 400 dilution of haemolytic serum. The results were read after a further period of incubation lasting two hours.

It will be seen that when a 1 in 160 dilution of antiserum was used no precipitate was formed in the simple mixtures of antigen and 
antibody, while the addition of this quantity of the homologous antigen produced definite fixation of complement. In the series of tubes which received the solution of euglobulin, definite turbidity occurred in three of the tubes.

This result was supported by the results of numerous similar experiments in which various antigens and antiserums were employed. In all these experiments the same method was employed. Precipitation and complement fixation experiments were carried out in which various quantities of the antigen were mixed with various quantities of the antiserum. In this way the dilution of antiserum was determined which just failed to produce visible precipitation but was nevertheless effective for the fixation of complement. To such a dilution of antiserum was then added a suitable dilution of the antigen together with the euglobulin preparation. In such a mixture definite precipitation was found to take place.

As a result of the reaction which takes place between antigen and antibody the particles of euglobulin of the guinea-pig serum are aggregated and precipitated. The mid-piece fraction of the complement is probably fixed or bound by this euglobulin precipitate in precisely the same manner as it is fixed by the euglobulin precipitate which is produced by the action of carbon dioxide or weak hydrochloric acid. The precipitation of the euglobulin of the guinea-pig serum is probably an essential part of the mechanism of complement fixation.

These experiments do not, of course, afford any evidence as to the mechanism by which the euglobulin of guinea-pig serum is precipitated by a suitable mixture of antigen and antiserum. It is possible that the euglobulin is adsorbed by minute and invisible particles of precipitate formed in the mixture of antigen and antibody. We have, however, at the present time no knowledge of the mechanism by which a precipitate is formed in a simple mixture of antigen and antibody, and such knowledge is probably essential to a complete understanding of the mechanism of complement fixation.

Is it possible to recover the mid-piece of the complement from the precipitate which occurs in a mixture of antigen, antibody and complement?

The experiments described in the previous paragraph suggest that the fixation of complement by a mixture of antigen and antibody is a reaction similar to the fixation of complement by the euglobulin precipitate produced by treating guinea-pig serum with carbon dioxide 
or weak hydrochloric acid. It was in fact shown that a suitable mixture of antigen and antibody does precipitate an euglobulin solution prepared from guinea-pig serum.

When complement is added to a suitable mixture of antigen and antibody we know that complement disappears. We are accustomed to test for this disappearance of complement by the addition of another antigen-antibody system, namely a mixture of corpuscles and haemolytic system. If the mixture after a period of incubation contains no free complement, no haemolysis takes place and we say that complement is fixed or bound. There are obviously two possibilities:

(1) The complement has been used up or destroyed.

(2) The complement has not been used up but has been rendered temporarily inactive and may by appropriate measures be recovered in an active state.

We know from the work of the authors recently quoted that it is chiefly the mid-piece of the complement which is bound by a mixture of a serum with its homologous antiserum, while the end-piece remains comparatively unaffected. If we add complement to a mixture of serum and antiserum, the mid-piece is taken up by the precipitate. Is the mid-piece used up or destroyed when it is bound or is it possible to recover it in an active state from the precipitate? If we observe the progress of haemolysis in an ordinary complement fixation experiment we must come to the conclusion that the mid-piece is not destroyed when it is bound. It is a common practice to add various quantities of an antiserum to a constant quantity of antigen. These various mixtures have, of course, various degrees of complement binding power. To all these tubes is then added a constant quantity of complement. The mixture is then incubated for an hour and blood and haemolytic serum are added to each tube. If we now watch the progress of haemolysis, we find that the tubes containing the antigen and antiserum controls are the first to dissolve. We may then remove the experiment from the incubator and record the results. If however we decide to continue the experiment we shall find that certain tubes which at first showed no trace of haemolysis, gradually begin to dissolve. In these tubes the mid-piece has been dissociated from the original antigen-antibody complex and is utilised by the corpuscles and haemolytic system. As the experiment is continued the weaker mixtures of the original antiserum and antigen give up more or less of their complement to the haemolytic system. After one or two hours very little further haemolysis takes place; that is to say, a point is reached when the weaker mixtures 
have given up their complement to the haemolytic system, while the mixtures of antigen and antibody, which had greater complement binding power, are able to retain the complement.

A more evident proof that the mid-piece is not destroyed may be obtained by adding various amounts of the haemolytic serum to a series of tubes each containing the same quantity of antigen, antiserum and complement. In a suitably arranged experiment it can be shown that the amount of complement fixation depends under these conditions on the quantity of the haemolytic serum which is added. There may, for example, be no haemolysis in the tube to which a 1 in 800 dilution of the haemolytic serum was added. That is to say all the complement has been fixed. While in a tube which contains precisely the same quantities of antigen, antiserum and complement, but to which a 1 in 200 dilution of the haemolytic serum has been added, a marked degree of haemolysis may take place. In both cases the complement was fixed but the stronger dose of haemolytic serum has been able to dissociate a certain amount of the complement from the original antigen-antibody complex.

It is obvious that the mid-piece is not destroyed when it is bound by a mixture of antigen and antibody.

If the precipitate obtained by the action of carbon dioxide or weak hydrochloric acid is collected, washed and re-dissolved, it is possible to show that the resulting solution does contain the active mid-piece fraction of the complement. Is it possible to demonstrate the presence of active mid-piece in the precipitate resulting from the mixture of antigen, antibody and complement?

Numerous experiments with this object were carried out, the results being at first extremely unsatisfactory. A satisfactory result was eventually obtained by the use of the following method:

In a test tube was placed 1 c.c. of fresh guinea-pig serum and 7 c.c. of saline solution. A second test tube contained a 1 in 100 dilution of normal human serum (the antigen), while a third test tube contained undiluted antiserum (rabbit $v$. man). All three tubes were allowed to stand for one hour in the cold room at a temperature of $0^{\circ} \mathrm{C}$. When all the ingredients were quite cold, 1 c.c. of the 1 in 100 dilution of the human serum and 1 c.c. of the undiluted antiserum were added to the tube containing 8 c.c. of diluted complement. The tube was then well shaken. The tube contained a bulk of 10 c.c. The concentration of the human serum (antigen) was 1 in 1000, of the fresh guinea-pig serum (complement) 1 in 10 and of the rabbit $v$. man serum (antiserum) 1 in 
10. The mixture was allowed to remain for three hours at $0^{\circ} \mathrm{C}$. during which time it was occasionally shaken. After three hours a definite deposit of precipitate had formed and the mixture was then centrifugalised in the cold room. The supernatant fluid which was quite clear was poured off and the precipitate was suspended in cold distilled water and again centrifugalised. This washing process was repeated and the precipitate was finally re-suspended in cold $0.85 \%$ saline solution. A uniformly turbid emulsion was obtained.

The materials used in the subsequent experiment (Table V) were:

(1) The suspension of the precipitate in normal saline solution.

(2) An ordinary mid-piece preparation made from guinea-pig serum by Liefmann's method.

(3) A 1 in 20 suspension of washed sheep red corpuscles.

(4) A I in 200 dilution of a haemolytic serum (rabbit $v$. sheep cells) the titre of which was 1 in 1200 .

All the above were cooled to $0^{\circ} \mathrm{C}$. before mixing.

(5) The supernatant fluid from the precipitation experiment.

(6) An ordinary end-piece preparation made from guinea-pig serum by Liefmann's method.

TABLE V.

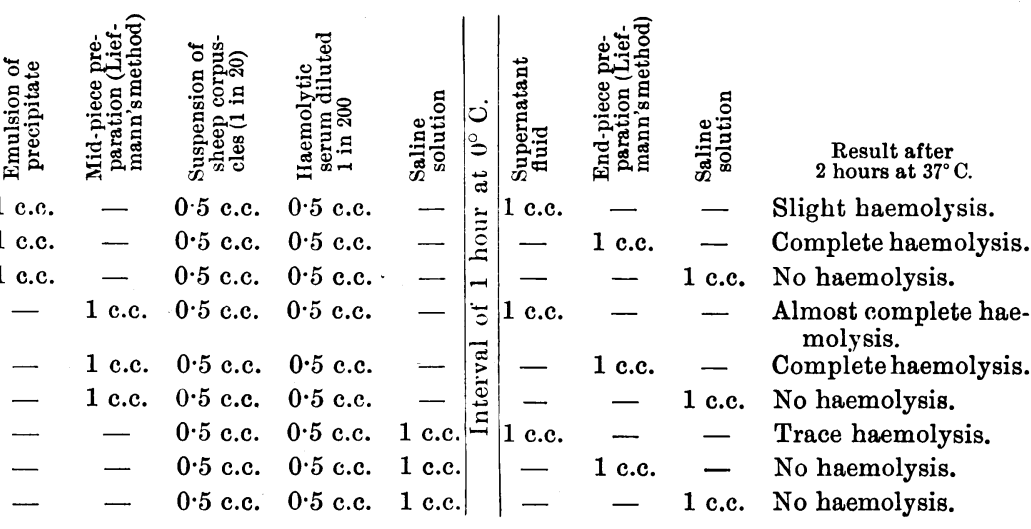

The mixtures shown in the table were then prepared. The corpuscles and haemolytic serum were mixed with the mid-piece preparation or the suspension of washed precipitate at a temperature of $0^{\circ} \mathrm{C}$. and allowed to remain at this temperature for one hour. All the tubes were then removed from the cold room and supernatant fluid, end-piece or saline solution was added to each tube as shown in the 
table. All the tubes were then incubated at $37^{\circ} \mathrm{C}$. for two hours. The degree of haemolysis was then observed and recorded.

Tube 3 shows that the precipitate did not contain the whole complement. No haemolysis was observed in the tube which contained corpuscles, haemolysin and precipitate. But the precipitate did contain the mid-piece fraction of the complement in an active state for complete haemolysis occurred in Tube 2. In this tube the mid-piece present in the precipitate was supplemented by the addition of end-piece prepared by Liefmann's method. The supernatant fluid contained a fair amount of end-piece and a trace of mid-piece. A trace of haemolysis was observed in the tube which contained corpuscles, haemolysin and supernatant fluid. The supernatant fluid contained sufficient end-piece to produce almost complete haemolysis when added to corpuscles persensitised with haemolysin and mid-piece prepared by Liefmann's method. Tube 1 shows that slight haemolysis occurred when the supernatant fluid was added to a mixture of corpuscles, haemolysin and suspended precipitate. In this case the end-piece present in the supernatant fluid was probably taken up by the turbid emulsion of the precipitate and was unable to produce its full effect.

The original mixture of human serum and anti-human serum had fixed the greater part but not quite all of the mid-piece fraction of the complement. By re-suspending the washed precipitate it was possible to show that the mid-piece taken up by the precipitate was still in an active state and able to take its part in the lysis of red corpuscles if supplemented by the action of a suitable quantity of end-piece.

This experiment shows that a mixture of antigen and antibody fixes or binds the mid-piece but does not use it up or render it inactive. The precipitate in this experiment also took up a considerable amount of the end-piece. The absorbed end-piece could not be demonstrated in the precipitate.

The main result attained by this experiment was to show that the mechanism of the fixation of complement by a mixture of antigen and antibody is essentially the same as the mechanism of the preparation of the two fractions of the complement by Liefmann's carbon dioxide method. In both cases a precipitate is formed which can be separated, washed and shown to contain the mid-piece fraction of the complement.

It will be noticed that great pains were taken to keep the precipitate cold both during and after its formation. When the experiment was attempted at a higher temperature it was not found possible to re-suspend the precipitate in a satisfactory manner. At any rate it was 
not possible to demonstrate in it the presence of active mid-piece. When the experiment was carried out at $0^{\circ} \mathrm{C}$. a fine emulsion of the precipitate was obtained and partial solution of the precipitate appeared to take place. We have found (Ledingham and Dean, 1912) that the same precautions as to the temperature are necessary in carrying out Liefmann's method. The guinea-pig serum is diluted with nine parts of ice-cold water and the mixture is kept in an ice bath while it is being

TABLE VI. (Part I.) Preliminary Precipitation Experiment.

$\begin{array}{ccc}\begin{array}{c}\text { Quantity of normal } \\ \text { human serum diluted } \\ \text { to } 0.5 \text { c.c. }\end{array} & \begin{array}{c}\text { Concentration of the } \\ \text { human serum in the mixture of } \\ \text { antigen, antibody and complement }\end{array} \\ 1 & 0.1 \text { c.c. } & 1 \text { in } 50 \\ 2 & 0.05 \text { c.c. } & 1 \text { in } 100 \\ 3 & 0.025 \text { c.c. } & 1 \text { in } 200 \\ 4 & 0.0125 \text { c.c. } & 1 \text { in } 400 \\ 5 & 0.00625 \text { c.c. } & 1 \text { in } 800 \\ 6 & 0.003125 \text { c.c. } & 1 \text { in } 1600 \\ 7 & 0.0015625 \text { c.c. } & 1 \text { in } 3200\end{array}$

TABLE VI. (Part II.) Haemolytic Experiment.

\begin{tabular}{|c|c|c|c|}
\hline & (A) & (B) & (C) \\
\hline $\begin{array}{l}1 \text { c.c. } \\
\text { suspended pre- } \\
\text { cipitate from }\end{array}$ & $\begin{array}{l}\text { +1 c.c. } \\
\text { supernatant } \\
\text { fluid }\end{array}$ & $\begin{array}{l}\text { +1 c.c. end-piece } \\
\text { prepared by } \\
\text { Lielmann's method }\end{array}$ & $\begin{array}{l}\text { +1 c.c. } \\
\text { saline } \\
\text { solution }\end{array}$ \\
\hline 1 & & & \\
\hline 2 & & & \\
\hline 3 & & & \\
\hline 4 & & & \\
\hline 5 & & & \\
\hline 6 & & & \\
\hline 7 & & & \\
\hline
\end{tabular}


TABLE VI. (Part III.)

\begin{tabular}{|c|c|}
\hline $\begin{array}{l}\text { 1 c.c. } \\
\text { supernatant } \\
\text { fluid from }\end{array}$ & $\begin{array}{c}\text { (D) } \\
\text { +1 c.c. mid-piece } \\
\text { prepared by } \\
\text { Liefmann's method }\end{array}$ \\
\hline 1 & \\
\hline 2 & \\
\hline 3 & \\
\hline 4 & \\
\hline 5 & \\
\hline 6 & \\
\hline 7 & \\
\hline
\end{tabular}

saturated with carbon dioxide. The precipitated globulin must be washed with cold distilled water and finally re-suspended in cold saline solution. Unless these precautions are carried out a satisfactory midpiece preparation is not obtained.

On the relative amounts of mid-piece and end-piece taken up by the various proportions of antigen and antibody.

It will be noticed in the table illustrating the last experiment that the precipitate fixed the greater part but not quite all of the mid-piece. The supernatant fluid on the other hand contained a considerable amount but certainly not all of the end-piece. The experiment recorded in Table VI was undertaken with the object of determining the relative amounts of mid-piece and end-piece taken up by various mixtures of antigen and antibody. The materials employed were normal human serum (antigen), rabbit $v$. man serum (antibody), fresh guinea-pig serum, mid-piece and end-piece fractions prepared by Liefmann's method. 
A series of quantities of the human serum from 0.1 c.c. to 0.0015625 c.c. were measured out into seven tubes. The human serum was diluted in every case to 0.5 c.c. The tubes were then placed in the cold room at $0^{\circ} \mathrm{C}$. The necessary quantities of antiserum, of complement and of saline were at the same time put in the cold room. At the end of one hour 4 c.c. of a 1 in 8 dilution of the guinea-pig serum was added to each tube and 0.5 c.c. of the undiluted antiserum. The concentration of the antiserum and of the complement was in each tube 1 in 10. The concentration of the antigen in the various tubes is shown in the table.

The antigen, complement and antiserum were mixed in the cold room and then left at $0^{\circ} \mathrm{C}$. for three hours. The method was precisely the same as that used in the last experiment (Table VI). The precipitation from each tube was separated from the supernatant fluid, washed, and re-suspended in 5 c.c. of cold saline. A mixture of equal parts of a 1 in 20 suspension of sheep corpuscles with a 1 in 200 dilution of haemolysin was prepared and 1 c.c. of this mixture was added to 1 c.c. of the suspension of precipitate from each of the seven tubes. Three such mixtures were prepared from the precipitate of each of the seven tubes of the original experiment.

At the same time 14 tubes were prepared containing 1 c.c. of the blood and haemolysin mixture and 1 c.c. of the ordinary mid-piece preparation. All these tubes were left for one hour at $0^{\circ} \mathrm{C}$. The tubes were then removed from the cold room.

The tubes containing suspended precipitate received in each case either 1 c.c. of the corresponding supernatant fluid, 1 c.c. of end-piece preparation, or 1 c.c. of saline solution. The tubes containing the midpiece preparation received either 1 c.c. of a supernatant fluid or 1 c.c. of saline solution. All the tubes were then incubated for two hours at $37^{\circ} \mathrm{C}$. when the results were read and recorded.

It should be stated that the mid-piece and end-piece preparations - were carefully tested and shown to be pure.

Column $\mathrm{E}$ shows the amount of complement remaining free in the supernatant fluid. The amount of complement fixed increased as the relative concentration of human serum (antigen) in the original mixture was diminished. In no case was all the complement fixed; in no case was all the mid-piece fixed. The original mixtures, it will be seen, contained a large quantity of complement ( 0.5 c.c. guinea-pig serum).

Column B shows that the mid-piece had been taken up by the various precipitates and that it remained in an active condition. By 
comparing the results in columns $\mathrm{B}$ and $\mathrm{E}$, it is seen that the amount of mid-piece taken up by the precipitate increased as the concentration of the antigen in the original mixture diminished.

Column D shows that end-piece was fixed, at any rate by the mixtures in Tubes 5, 6 and 7 .

The experiment shows that a precipitate produced by the interaction of antigen and antiserum binds both mid-piece and end-piece. The mid-piece is far more readily bound than the end-piece but the experiment shows that traces of mid-piece may remain free after a considerable amount of end-piece has been fixed. After the mid-piece has been fixed by a precipitate it can be still demonstrated in an active condition in the suspension of the precipitate.

It was not found possible to demonstrate the presence of active endpiece in the precipitate and it must be assumed that the end-piece is rendered inactive when it is fixed.

\section{Summary AND Conclusions.}

(1) If a series of dilutions of an antiserum are prepared, a dilution can be selected which when mixed with an appropriate quantity of the homologous antigen forms no precipitate but nevertheless binds complement. If complement is added to such a mixture of antigen and antiserum a precipitate appears after an interval of six to twentyfour hours.

(2) By using an appropriate mixture of antigen and antiserum the amount of the precipitate can be increased, within certain limits, by increasing the amount of guinea-pig serum (complement) present in the mixture.

(3) Similar results can be obtained if an euglobulin solution prepared from guinea-pig serum is substituted for the normal guineapig serum.

(4) A suitable mixture of antigen and antiserum precipitates the euglobulin of guinea-pig serum in a manner which may be compared with the precipitation of euglobulin by carbon dioxide.

(5) By keeping a precipitating mixture of antigen, antiserum and complement at a temperature of $0^{\circ} \mathrm{C}$. it is possible to demonstrate that the resulting precipitate contains the mid-piece fraction of the complement in an active state.

The mid-piece fraction is not used up when it is bound by a mixture of serum with its homologous antiserum. 
(6) The precipitate which results from the interaction of antigen and antiserum fixes both fractions of the complement. The mid-piece is fixed much more readily than the end-piece but it is possible to demonstrate a stage when a considerable quantity of end-piece has been bound while a small quantity of mid-piece still remains free.

(7) The results obtained in these experiments show that the fixation of the fractions of the complement by a mixture of antigen and antiserum is essentially similar to the fixation produced by suspensions of barium sulphate and similar complement fixing substances. These experiments confirm the recent work of Gengou on this subject.

(8) The particles of a precipitate probably adsorb the euglobulin of the guinea-pig serum and this adsorption of euglobulin is an essential part of the mechanism of complement fixation.

\section{REFERENCES.}

Amako, T. (1910). Experimentelle Beiträge zum Mechanismus der Komplementwirkung. Zeitschr. f. Immunitätsforsch. viII. 168.

Barikine, W. (1910). Contribution à l'Étude sur la Conglutination du Précipité spécifique. Centralbl. f. Bakteriol. Abt. I. Lvi. 150.

Bordet, J. and GAY, F. P. (1906). Sur les Relations des Sensibilisatrices avec l'Alexine. Ann. Inst. Pasteur, xx. 467.

Bordet, J. and Streng, O. (1909). Les Phénomènes d'Adsorption et la Conglutinine du Sérum de Bœuf. Centralbl. f. Bakteriol. Abt. I. xuIx. 260.

Brand, E. (1907). Ueber das Verhalten der Komplemente bei der Dialyse. Berlin. klin. Wochenschr. xuIv. 1075.

Chapman, H. G. (1910). On the weight of Precipitate obtainable in Precipitin Interactions. Proc. Roy. Soc. Series B, Lxxxir. 398.

Dean, H. R. (1911). Studies in Complement Fixation with Strains of Typhoid, Paratyphoid and allied Organisms. Proc. Roy. Soc. Med. Iv. (Pathological Section) p. 251.

Dean, H. R. (1911). The Relation between the Fixation of Complement and the Formation of a Precipitate. Proc. Roy. Soc. Med. v. (Pathological Section) p. 62 .

Dean, H. R. (1911). On the Factors concerned in Agglutination. Proc. Roy. Soc. Series B, LXXXI. 416.

Ferrata, A. (1907). Die Unwirksamkeit der komplexen Hamolysine in salzfreien Lösungen und ihre Ursache. Berlin. klin. Wochenschr. xuIv. 366.

GAY, F. P. (1905). La déviation de l'alexine dans l'hémolyse. Ann. Inst. Pasteur, XIX. 593.

GAY, F. P. (1905). The Fixation of Alexines by Specific serum precipitates. Centralbl. f. Bakteriol. Abt. I. Orig. xxxix. 603.

Gengou, O. (1911). Note sur les Relations de l'Alexine avec les microbes sensibilisés. Zeitschr. f. Immunitätsforsch. II. 143. 
Henderson-Smith, J. (1910). On the Structure of Complement in Relation to Deviation. Brit. Med. Journ. II. 1433.

Ledingham, J. C. G. and Dean, H. R. (1912). The Action of the ComplementFractions on a Tropin B. typhosus System. Journ. of Hygiene, xII. 152.

LiefmanN, H. (1909). Ueber den Mechanismus der Seroreaktion der Lues. München. med. Wochenschr. LVI. 2097.

MeIER, G. (1909). Die Komplementbindung mit besonderer Berücksichtigung ihrer praktischen Anwendung. Jahresber. ü. Ergebnisse der Immunitätsforschung, Stuttgart, IV. 58.

Moreschi, C. (1906). Zur Lehre von den Antikomplementen. Berlin. klin. Wochenschr. XLIII. 100.

Muir, R. and Browning, C. H. (1906). On the Action of Complement as Agglutinin. Journ. of Hygiene, vi. 20.

Moir, R. and Martin, W. B. M. (1906). On the Deviation of Complement by a Serum and its Antiserum, and its relation to the Precipitin test. Journ. of Hygiene, vI. 265.

Neisser, M. and SACHS, H. (1905). Ein Verfahren zum forensischen Nachweiss der Herkunft des Blutes (Ablenkung hämolytischer Komplemente). Berlin. klin. Wochenschr. XuII. 1388.

Neisser, M. and SACHS, H. (1906). Die forensische Blutdifferenzierung durch antihämolytische Wirkung. Ibid. xLIII. 67.

Pfeiffer, F. and Moreschi, C. (1906). Ueber scheinbare Antikomplementäreund Antiambozeptorenwirkungen präcipitierenden Sera in Tierkörper. Ibid. XIIII. 45.

SaChs, H. and Altmann, K. (1909). "Komplementbindung." Handbuch der Pathogenen Mikroorganismen (Kolle und Wassermann), Ergänzungsb. II. p. 476.

Sachs, H. and Altmann, K. (1909). " Hamolysine und Cytotoxine des Blutserums." Handb. d. Technik u. Methodik d. Immunitätsforschung (Kraus und Levaditi), II. 969.

SaChs, H. and Bolkowska, G. (1910). Beiträge zur Kenntnis der komplexen Konstitution der Komplemente. Zeitschr. f. Immunitätsforsch. vir. 778.

Skwirsky, P. (1910). Ueber den Mechanismus der Komplementbindungen. Ibid. v. 538.

Streng, O. (1909). Studien über das Verhalten des Rinderserums gegenüber den Mikroben. Centralbl. f. Bakteriol. Abt. I. L. 47.

WassermanN, A. and BrUCK, C. (1905). Ist die Komplementbindung beim Entstehen spezifischer Niederschläge eine mit der Präzipitierung zusammenhängende Erscheinung oder Ambozeptorenwirkung? Med. Klinik, I. 1409.

Welsh, D. A. and Chapman, H. G. (1906). On the Main Source of Precipitable Substance, and on the Rôle of the Homologous Proteid in Precipitin Reactions. Proc. Roy. Soc. Series B, Lxxvir. 297.

Welsh, D. A. and Chapman, H. G. (1908). On the Weight of Precipitum in Precipitin Interactions, with Small Weights of Homologous Protein. Proc. Roy. Soc. Series B, Lxxx. 161.

Welsh, D. A. and Chapman, H. G. (1911). Beitrag zur Erklärung der Präzipitinreaktion. Zeitschr. f. Immunitätsforsch. Ix. 517. 